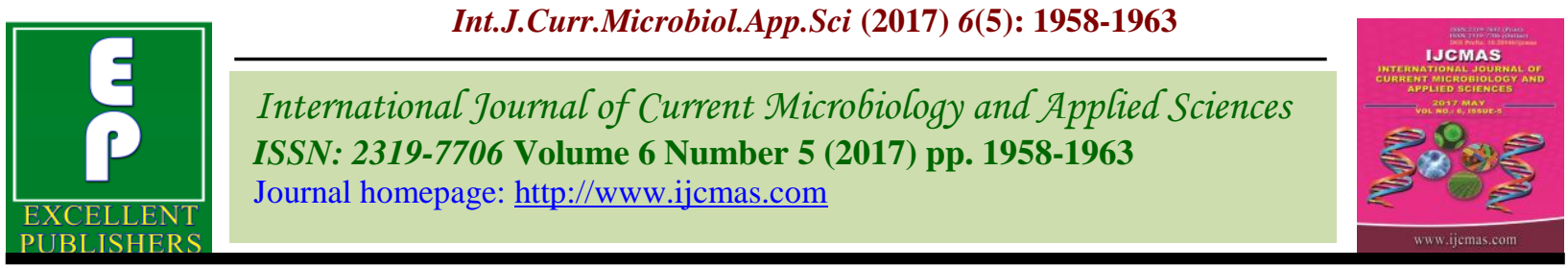

Original Research Article

https://doi.org/10.20546/ijcmas.2017.605.218

\title{
Efficacy of Some New Insecticides against Diamond Back Moth (Plutella xylostella L.) on Cauliflower
}

\author{
S.K. Dotasara ${ }^{1 *}$, N. Agrawal $^{1}$, N. Singh ${ }^{2}$ and Dinesh Swami ${ }^{3}$ \\ ${ }^{1}$ Department of Entomology, CSAUA \& T, Kanpur-208002, India \\ ${ }^{2}$ Division of Entomology, RARI, SKNAU, Jobner, India \\ ${ }^{3}$ Department of Entomology, SKNAU, Jobner-303329, India \\ *Corresponding author
}

\begin{abstract}
A B S T R A C T
Keywords

Plutella xylostella,

Cauliflower,

Diamond Back

Moth insecticides.

Article Info

Accepted:

19 April 2017

Available Online:

10 May 2017

The efficacy of different insecticides against the diamondback moth (DBM) on cauliflower was studied at CSAUA\&T, Kanpur. Among the various insecticides evaluated against the DBM, spinosad (45 SC @ 0.5ml/ litre) treated cauliflower plot showed highest per cent reduction over control ( $89.97 \%)$ with less number of larvae (0.58 larvae/ plant). The larval count and per cent reduction over control in the different treated plots ranged from 0.58 to 3.94 and 89.97 to 41.37 respectively as against 8.79 numbers of larvae in untreated control. Flubendiamide $48 \mathrm{SC} @ 0.3 \mathrm{ml} /$ litre and chlorantriniliprole $18.5 \mathrm{SC} @ 0.3 \mathrm{~g}$ / litre were next effective pesticides to reduce the pest incidence significantly. All the treatments were also observed to be significantly superior over control.
\end{abstract}

\section{Introduction}

Diamond back moth, Plutella xylostella L. (Plutellidae: Lepidoptera) is the most important pest causing severe yield loss to cauliflower every year. The damage caused by diamond back moth, P. xylostella L. has been estimated globally to cost US\$ 1 billion in direct losses and control costs (Grzywacz et al., 2010). The use of synthetic insecticides is the main control strategy (Kibata, 1996). This pest has developed resistance against all major groups of pesticides, including Bacillus thuringiensis bacterial based bio-pesticides (Tabashnik et al., 1990; Zhou et al., 2011). In India, Krishnamoorthy (2004) reported that $52 \%$ yield loss on cauliflower due to diamond back moth.
Farmers are compelled to use chemical insecticides in order to cultivate lucratively, as traditional and cultural practices alone cannot give satisfactory control over the pest menace. Frequent use of chemical insecticides at higher doses results in development of insecticide resistance in $P$. xylostella against a range of insecticides in different parts of India (Talekar et al., 1990 and Vastrad et al., 2003). This has necessitated the use of alternative eco-friendly insecticides to sustain the management of diamondback moth and the development of resistance against these traditional insecticides can be easily breakdown by using the newer group of molecules. 
In this context, the efficacy of few newer insecticides viz., flubediamide, chlorantriniliprole, emamectin benzoate, fipronil, imidacloprid, spinosad and neem oil etc., were evaluated under field condition for their comparative efficacy against diamondback moth on cauliflower.

\section{Materials and Methods}

A field experiment on cauliflower var. Pusa Snowball-16 was laid out during Rabi season 2014-15 at Student Instructional Farm in Chandra Shekhar Azad University of Agriculture and Technology, Kanpur (U.P.) India, in Randomised Block Design (RBD) with eight treatments including untreated control each replicated thrice. Each treatment schedule comprised two sprays, except treatment No. 8 which was taken as untreated control. The present study was carried out to evaluate the efficacy of newer insecticides against diamond back moth, $(P$. xylostella Linn.) of cauliflower.

Required numbers of plots having a size of $3 \mathrm{~m}$ X $3 \mathrm{~m}$ were prepared to accommodate all the 8 treatments, each having 3 replications. Along with two main irrigation channels of $1 \mathrm{~m}$ width at the two length sides of the experimental field, two sub-irrigation channels $1.0 \mathrm{~m}$ were provided in between 3 replications and each plot was separated by a trench of $0.5 \mathrm{~m}$ so that drifting of different insecticides during spraying was minimized.

First spraying was applied after 75 days of transplanting followed by second spraying at 15 days interval. The percentage of reduction in insect pest population was calculated on the basis of pre and post treatment count after 7 and 15 days of each spraying. To estimate the larval population of diamondback moth, direct visual counting method was used (Lal, 1998). The mean number of DBM larval population were recorded from randomly 5 selected plants in each plot and same expressed as numbers of larval population /plant during morning hours between 6:30 a.m. to 8.00 a.m. when most of the insect species are less active. The observations on DBM population were recorded at weekly intervals to monitor the ETL of the pest and to decide the time of application of insecticides. Pre-treatment counts of DBM larvae were taken one day prior in all the plots at each time just before the application of insecticides. Post-treatment counts of DBM larvae were taken after $7^{\text {th }}$ and $15^{\text {th }}$ days of application of treatments. Similar observations were also taken after $2^{\text {nd }}$ applications of treatments.

The formula used for the calculation of percentage reduction of pest population over control using following formula giving by Henderson and Tilton (1955) referring it to be modification of Abbott (1925).

$$
\text { Per cent efficacy }=\left(1-\frac{\mathrm{Ta}}{\mathrm{Ca}} \times \frac{\mathrm{Cb}}{\mathrm{Tb}}\right) \times 100
$$

Where,

$\mathrm{Ta}=$ Number of insects on treated plots after insecticidal application

$\mathrm{Tb}=$ Number of insects in treated plots before insecticidal application

$\mathrm{Ca}=$ Number of insects in untreated plots after insecticidal application

$\mathrm{Cb}=$ Number of insects in untreated plots before insecticidal application

The data on percentage reduction of DBM population were transformed into angular values (Bliss, 1937) and natural enemies in to $\sqrt{x+0.5}$ (Gomez and Gomez, 1976) and subjected to analysis of variance.

\section{Results and Discussion}

The perusal of Table 1 reveals that larval population of DBM was statistically uniform varying from 6.26 to 7.56 larvae per plant in all plots before application of insecticides. 
Table.1 Efficacy of newer insecticides against Plutella xylostella Linn., infesting on cauliflower during Rabi, 2014-15

\begin{tabular}{|c|c|c|c|c|c|c|c|c|c|c|c|c|c|}
\hline & & & & & No. of DBM & arvae / & Plant & & & & & & \\
\hline & & & & & irst spray & & & & Secon & spray & & & \\
\hline S.N. & Treatment & Dose & DBS & $\begin{array}{c}7 \\
\text { DAS }\end{array}$ & $\begin{array}{c}\% \\
\text { Reduction } \\
\text { over } \\
\text { control }\end{array}$ & $\begin{array}{c}15 \\
\text { DAS }\end{array}$ & $\begin{array}{c}\% \\
\text { Reduction } \\
\text { over } \\
\text { control }\end{array}$ & $\begin{array}{c}7 \\
\text { DAS }\end{array}$ & $\begin{array}{c}\% \\
\text { Reduction } \\
\text { over } \\
\text { control }\end{array}$ & $\begin{array}{c}15 \\
\text { DAS }\end{array}$ & $\begin{array}{c}\% \\
\text { Reduction } \\
\text { over } \\
\text { control }\end{array}$ & $\begin{array}{c}\text { Average } \\
\text { larval } \\
\text { count }\end{array}$ & $\begin{array}{c}\text { Average } \\
\% \\
\text { Reductio } \\
\text { n over } \\
\text { control } \\
\end{array}$ \\
\hline 1 & Fipronil 5 SC & $\begin{array}{c}1.0 \\
\mathrm{ml} / \mathrm{l}\end{array}$ & $\begin{array}{c}6.67 \\
(2.68)^{*}\end{array}$ & $\begin{array}{c}4.17 \\
(2.16)\end{array}$ & 45.76 & $\begin{array}{c}4.83 \\
(2.31)\end{array}$ & 41.26 & $\begin{array}{c}3.07 \\
(1.89)\end{array}$ & 44.46 & $\begin{array}{c}2.50 \\
(1.73)\end{array}$ & 52.76 & $\begin{array}{c}3.64 \\
(2.02)\end{array}$ & 46.06 \\
\hline 2 & $\begin{array}{l}\text { Chlorantriniliprole } \\
18.5 \mathrm{SC}\end{array}$ & $\begin{array}{l}0.3 \\
\mathrm{~g} / 1\end{array}$ & $\begin{array}{c}6.26 \\
(2.60)\end{array}$ & $\begin{array}{c}0.93 \\
(1.20)\end{array}$ & 87.07 & $\begin{array}{c}1.37 \\
(1.37)\end{array}$ & 82.32 & $\begin{array}{c}0.23 \\
(0.86)\end{array}$ & 85.05 & $\begin{array}{c}0.18 \\
(0.83)\end{array}$ & 87.75 & $\begin{array}{c}0.68 \\
(1.06)\end{array}$ & 85.55 \\
\hline 3 & $\begin{array}{l}\text { Flubendiamide } 48 \\
\text { SC }\end{array}$ & $\begin{array}{c}0.3 \\
\mathrm{ml} / \mathrm{l}\end{array}$ & $\begin{array}{c}7.15 \\
(2.77)\end{array}$ & $\begin{array}{c}0.97 \\
(1.21)\end{array}$ & 88.26 & $\begin{array}{c}1.47 \\
(1.40)\end{array}$ & 83.37 & $\begin{array}{c}0.20 \\
(0.84)\end{array}$ & 88.06 & $\begin{array}{c}0.15 \\
(0.81)\end{array}$ & 90.66 & $\begin{array}{c}0.70 \\
(1.06)\end{array}$ & 87.59 \\
\hline 4 & $\begin{array}{c}\text { Emamectin } \\
\text { benzoate } 5 \mathrm{SG}\end{array}$ & $\begin{array}{l}0.2 \\
g / 1\end{array}$ & $\begin{array}{c}7.56 \\
(2.84)\end{array}$ & $\begin{array}{c}1.50 \\
(1.41)\end{array}$ & 82.77 & $\begin{array}{c}2.23 \\
(1.65)\end{array}$ & 76.05 & $\begin{array}{c}0.43 \\
(0.97)\end{array}$ & 83.01 & $\begin{array}{c}0.37 \\
(0.93)\end{array}$ & 85.01 & $\begin{array}{c}1.13 \\
(1.24)\end{array}$ & 81.71 \\
\hline 5 & Neem oil $2 \%$ & $\begin{array}{l}2.0 \\
\mathrm{ml} / \mathrm{l}\end{array}$ & $\begin{array}{c}6.77 \\
(2.70)\end{array}$ & $\begin{array}{c}2.23 \\
(1.65)\end{array}$ & 71.36 & $\begin{array}{c}3.07 \\
(1.89)\end{array}$ & 63.28 & $\begin{array}{c}0.87 \\
(1.17)\end{array}$ & 75.26 & $\begin{array}{c}0.77 \\
(1.13)\end{array}$ & 77.17 & $\begin{array}{c}1.74 \\
(1.46)\end{array}$ & 71.77 \\
\hline 7 & Spinosad 45 SC & $\begin{array}{c}0.5 \\
\mathrm{ml} / \mathrm{l}\end{array}$ & $\begin{array}{c}7.33 \\
(2.80)\end{array}$ & $\begin{array}{c}0.73 \\
(1.11)\end{array}$ & 91.32 & $\begin{array}{c}1.33 \\
(1.35)\end{array}$ & 85.27 & $\begin{array}{c}0.15 \\
(0.81)\end{array}$ & 90.15 & $\begin{array}{c}0.10 \\
(0.77)\end{array}$ & 93.15 & $\begin{array}{c}0.58 \\
(1.01)\end{array}$ & 89.97 \\
\hline 8 & Untreated control & - & $\begin{array}{c}6.83 \\
(2.71)\end{array}$ & $\begin{array}{c}7.87 \\
(2.89)\end{array}$ & & $\begin{array}{c}8.43 \\
(2.99)\end{array}$ & & $\begin{array}{c}9.63 \\
(3.18)\end{array}$ & & $\begin{array}{c}9.23 \\
(3.12)\end{array}$ & & $\begin{array}{c}8.79 \\
(3.04)\end{array}$ & \\
\hline & $\mathrm{SE}(\mathrm{m}) \pm$ & - & 0.017 & 0.026 & & 0.055 & & 0.050 & & 0.041 & & & \\
\hline & $\mathrm{CD}(\mathrm{P}=0.05)$ & - & 0.053 & 0.079 & & 0.169 & & 0.154 & & 0.126 & & & \\
\hline
\end{tabular}

DBS - Days before spray, DAS -Days after spray, figures in parentheses $\sqrt{x+0.5}$ transformed values 
The larval population was significantly decreased in all treated plots after application in comparison to untreated control. Spinosad 45 SC @ 0.5 ml/ litre had its superiority and it recorded 0.58 larvae per plant and provided 89.97 per cent reduction in larval population over untreated control. Flubendiamide 48 SC @ $0.3 \mathrm{ml} /$ litre was statistically at par with chlorantriniliprole $18.5 \mathrm{SC} @ 0.3 \mathrm{~g} /$ litre with 0.70 and 0.68 larvae per plant and they provided 87.59 and 85.55 per cent reduction in population over untreated control, respectively. Effectiveness of emamectin benzoate 5 SG @ $0.2 \mathrm{~g} /$ litre and neem oil 2\% @ $2.0 \mathrm{ml} /$ litre was 81.71 and 71.77 per cent reduction over untreated control with 1.13 and 1.74 larvae of DBM. The efficacy of fipronil $5 \mathrm{SC} @ 1.0 \mathrm{ml} /$ litre and imidacloprid 17.8 SL @ $0.2 \mathrm{~g}$ / litre highly toxic followed by was significantly poor but they were superior over untreated control against DBM (Table-1).

After 15 days of the first spray of treatments, the data revealed that all the treatments were superior over untreated control. Spinosad 45 SC @ 0.5ml/ litre had its superiority and provided 85.27 per cent reduction in larval population over untreated control. Flubendiamide 48 SC @ $0.3 \mathrm{ml} /$ litre was statistically at par with chlorantriniliprole 18.5 SC @ $0.3 \mathrm{~g} /$ litre recording 83.37 and 82.32 per cent reduction in larval population over untreated control, while emamectin benzoate 5 SG @ 0.2 g/ litre was also effective with 76.05 per cent reduction in larval population over untreated control. The performance of fipronil $5 \mathrm{SC} @ 1.0 \mathrm{ml} /$ litre and imidacloprid 17.8 SL@ 0.2 g/ litre was significantly poor but better than untreated control.

The results (Table-1) revealed that reduction in DBM population in all the treatments was noticed; spinosad 45 SC @ $0.5 \mathrm{ml} /$ litre highly toxic followed by flubendiamide 48 SC @ $0.3 \mathrm{ml} /$ litre. The remaining new chemicals, chlorantriniliprole18.5 SC @ 0.3 g/ litre, emamectin benzoate 5 SG @ 0.2 g/ litre, neem oil 2\%@2.0 ml/litre, fipronil 5 SC@ $1.0 \mathrm{ml} /$ litre and imidacloprid $17.8 \mathrm{SL}$ @ $0.2 \mathrm{~g} /$ litre were moderately toxic. Imidacloprid17.8 SL @ $0.2 \mathrm{~g} /$ litre was found least in controlling DBM.

The present studies revealed that spinosad, flubendiamide, chlorantriniliprole and emamectin benzoate were effective in managing diamond back moth in cauliflower. Our results, suggest that spinosad was most effective insecticide in both sprays. Our findings are supported by Mandal et al., (2009) who reported the superiority of spinosad (Spinotor $45 \mathrm{SC} ; 0.4 \mathrm{ml} / \mathrm{L}$ ) against diamond back moth, $P$. xylostella. Dhawan et al., (2009) evaluated chlorantraniliprole @ 30 $\mathrm{g}$ a.i./ ha which was the most effective treatment for the control of bollworm complex on cotton. Deshmukh et al., (2010) also revealed that flubendiamide $0.007 \%$, spinosad $0.009 \%$ and emamectin benzoate $0.0015 \%$ were most effective in reducing the Helicoverpa armigera population and pod damage in chickpea. Venkateswarlu et al., (2011) also showed that Chlorantraniliprole (18.5\% SC @ $10 \mathrm{~g}$ a.i./ ha) had highest PROC of diamond back moth, Plutella xylostella (83.65\% and $82.08 \%)$. Shankara Murthy and Sannaveerappanavar (2013) also reported that the new molecules, flubendiamide, spinosad and emamectin benzoate were highly toxic to the susceptible DBM strain. Nikam et al., (2014) also reported effectiveness of spinosad against this pest, who observed the better efficacy of spinosad against DBM. Lal and Meena (2001) also reported similar result which shows that besides imidacloprid other insecticides were found less effective against diamond back moth.

\section{Acknowledgement}

The authors are thankful to The Head, Department of Entomology, Chandra Shekhar 
Azad University of Agriculture and Technology, Kanpur (U.P.) for providing facilities to conduct the experiments.

\section{References}

Abbott, W.S. 1925. A method of computing the effectiveness of an insecticide. $J$. Eco. Entomol., 18: 265-267.

Anonymous. 2014. Indian Horticulture Database, National Horticulture Board, Ministry of Agriculture, Government of India, 85, Institutional Area, Sector-18, Gurgaon-122015, India, pp. 144-151.

Bliss, C.I. 1937. Angles corresponding to percentage. Plant Protection, No. 12, Leningrad.

Deshmukh, S.G., Sureja, B.V., Jethva, D.M. and Chatar, V.P. 2010. Field efficacy of different insecticides against Helicoverpa armigera (Hubner) infesting chickpea. Legume Res., 33(4): 269-273.

Dhawan, A.K., Singh, R., Singh, K., and Sharma, M. 2009. Efficacy of chlorantraniliprole against bollworm complex on cotton. J. Insect Sci., (Ludhiana), 22(3): 248-253.

Gomez, K.A. and Gomez, A.A. 1976. Problem data: Statistical Procedures for Agricultural Research (II ed.). John Wiley and Sons, New York, pp. 272315.

Grzywacz, D., Rossbach, A., Rauf, A., Russel, D.A., Srinivasan, R. and Shelton, A.M. 2010. Current control methods for diamondback moth and other brassica insect pests and the prospects for improved management with lepidopteran - resistant $\mathrm{Bt}$ vegetable brassicas in Asia and Africa. Crop Prot., 29: 68-79.

Henderson, C.F. and Tilton, E.W. 1955. Tests with acaricides against brown wheat mite. J. Economic Entomol., 48(2): 157161.

Kibata, G.N. 1996. Diamondback moth
Plutella xylostella L. (Lepidoptera: Yponomeutidae), a problem pest of brassicae crops in Kenya. Proc. First Biennial Crop Protection Conf., 27-28 March, Nairobi, Kenya: 1-11.

Krishnamoorthy, A. 2004. Biological control of diamondback moth Plutella xylostella (L.), an Indian scenario with reference to past and future strategies. In Proceedings of the International Symposium (Eds AA Kirk D Bordat), $21-24$ October 2002, Montpellier, France, CIRAD, pp. 204-11.

Lal, O.P. 1998. Notes summer school on "Advance Technologies in Important Vegetable Crops, including Cole Crops". May 4-24, I.A.R.I. New Delhi, pp. 63-66.

Lal, O.P. and Meena, R.K. 2001. Effects of certain insecticides against diamondback moth, Plutella xylostella (L.) on cabbage under field condition. Pesticide Res. J., 13(2): 242-246.

Mandal, S.K., Kumar, R., Das, S. and Kumar, V. 2009. Field evaluation of some newer insecticides against the diamondback moth, Plutella xylostella (L.), on cauliflower. Pest Management and Economic Zool., 17(1):105-108.

Nikam, T.A., Chandele, A.G., Gade, R.S. and Gaikwad, S.M. 2014. Efficacy of chemical insecticides against diamond back moth, Plutella xylostella L. on cabbage under field condition. Trends in Biosci., 7(12): 1196-1199.

Shankara Murthy, M. and Sannaveerappanavar, V.T. 2013. Baseline values for susceptibility of Plutella xylostella L. (Plutellidae: Lepidoptera) to new insecticides. J. Ent. Res., 37(4): 293-296.

Tabashnik, B.E., Cushing, N.L., Finson, N. and Johnson, M.W. 1990. Field development of resistance to Bacillus thuringiensis in Diamondback moth (Lepidoptera: Plutellidae). J. Econ. 
Entomol., 83: 1671-1676.

Talekar, N.S., Yang, J.C. and Lee, S.T. 1990. Annotated Bibliography of Diamondback moth, vol., 2. Asian Vegetable Research and Development Centre, Taiwan. pp.199.

Vastrad, A.S., Lingappa, S. and Basavanagoud, K. 2003. Management of insecticide resistant populations of diamondback moth, Plutella xylostella (L.) (Yponomeutidae: Lepidoptera). Pest management in Horticultural Ecosystem, 9(1): 33-40.
Venkateswarlu, V., Sharma, R.K. and Sharma, K. 2011. Evalutation of ecofriendly insecticides against major insect pests of cabbage. Pesticide Res J., 23(2): 172-180.

Zhou, L., Huang, J., Xu, H. 2011. Monitoring resistance of field populations of diamondback moth Plutella xylostella L. (Lepidoptera: Yponomeutidae) to five insecticides in South China: A tenyear case study. Crop Prot., 30: 272278.

\section{How to cite this article:}

Dotasara, S.K., N. Agrawal, N. Singh and Dinesh Swami. 2017. Efficacy of Some New Insecticides against Diamond Back Moth (Plutella xylostella L.) on Cauliflower. Int.J.Curr.Microbiol.App.Sci. 6(5): 1958-1963. doi: https://doi.org/10.20546/ijcmas.2017.605.218 